\section{Comparison of night sky brightness above Zagreb and a nearby rural location} 2014-2017
The Mining-Geology-Petroleum Engineering Bulletin UDC: $551: 593$

DOI: $10.17794 / \mathrm{rgn} .2020 .2 .5$

Original scientific paper

\author{
Krešimir Pavlić'; Željko Andreić ${ }^{2}$ \\ Faculty of Mining, Geology and Petroleum Engineering, University of Zagreb, Pierottijeva 6, HR-10000, Zagreb \\ IORCID:0000-0003-3315-2900, kpavlic@rgn.hr \\ 2ORCID: 0000-0003-0175-8174, zandreic@rgn.hr
}

\begin{abstract}
The results of monitoring light pollution near the center of Zagreb at the Faculty of Mining, Geology and Petroleum Engineering (RGN) for the period 2012 - 2017 were presented in a recent article (Andreić, 2018). The question that remained unanswered is how the night sky brightness behaves in the suburbs of Zagreb and in the nearby rural area. This article attempts to give some answers to this question by analyzing data gathered at the rural site of Merenje, located north of Zagreb. The main conclusion drawn is that the night sky brightness at both sites follows very similar patterns for clear sky conditions and is often similar for cloudy conditions, too. For both sites, no significant increase in zenithal night sky brightness was found in the observed period of 2014 - 2017. Thus, at least for the areas north of Zagreb that are in the shadow of Medvednica Mountain, the contribution of the light pollution from Zagreb and its growing outskirts remains unaltered. The main difference is in the level of the night sky brightness, the average for the RGN site being 16.9 mag/ $\operatorname{arcsec}^{2}$ and $18.9 \mathrm{mag} / \operatorname{arcsec}^{2}$ for the Merenje site. Additionally, the cloudy conditions enhance the light pollution of Zagreb a lot more, the difference being about $3.2 \mathrm{mag} / \operatorname{arcsec}^{2}$ for RGN, in contrast to 1.9 mag/arcsec ${ }^{2}$ for the Merenje site. No measurements exist for areas to the south, so no conclusions can be made for the situation there. Last, but not least, it was found that in cloudy conditions, the stronger light pollution of Zagreb is proportionally more enhanced by the clouds/fog than the smaller levels of light pollution at the Merenje site.
\end{abstract}

\title{
Keywords:
}

Light pollution; night sky brightness; ALAN evolution; atmospheric effects.

\section{Introduction}

Light pollution (LP) (Hollan, 2008) is most simply defined as artificial light that spills at night into the environment, and is intensively studied today. For a short overview, the web pages of the International Dark Sky Association (IDA, 2020), or Wikipedia (Wiki, 2020) can be consulted. The ecological impact of light pollution is still not well understood, but a lot of research is in progress on both plant and animal life, including humans. A nice recent review of the current knowledge in this area is given in Krop-Benesch (2019).

The crucial parameter in such studies is the amount (intensity) and the duration of the light pollution. There is still no standard method of measuring the light pollution, but again, a lot of research has been put into resolving this question recently. A nice overview of measuring methods and instruments is given by Hänel et al. (2017). The instruments of our choice are Sky Quality meters (Unihedron, 2020), models SQM-LE (SQM-LE, 2020) and SQM-LU-DL (SQM-LU-DL, 2020).

Corresponding author: Krešimir Pavlić kpavlic@rgn.hr
Among several hundred articles that have appeared since our first article on LP monitoring in Zagreb (Andreić, 2018) was prepared, a few can be related to it, as follows: Ribas et al. (2017) studied the amplification of light pollution by clouds, with the conclusion that LP in a city increases dramatically with the presence of clouds, in accordance with conclusions from Andreić (2018). Yu et al. (2015) analyzed measurements of LP around the Seoul Capital Area (population 9.8 million) in 2009 and 2014, with the main conclusions that the clear night sky brightness at the brightest site was 16.3 and $16.5 \mathrm{mag} / \mathrm{arcsec}^{2}$ in 2009/2010 and 2014/2015, respectively, showing a decrease of about $0.2 \mathrm{mag} / \mathrm{arcsec}^{2}$ in 5 years. As a comparison, the corresponding values for Zagreb (Andreić, 2018) are $16.9 \mathrm{mag} / \operatorname{arcsec}^{2}$ and no change in the 5-year long period of observation. At a rural site about $50 \mathrm{~km}$ from the brightest site in Seoul, the results are 20.1 and $20.6 \mathrm{mag} / \mathrm{arcsec}^{2}$ in 2009/2010 and 2014/2015, with an even larger decrease of $0.5 \mathrm{mag} /$ $\operatorname{arcsec}^{2}$ in 5 years. Again, for the rural site about $30 \mathrm{~km}$ from the center of Zagreb, the corresponding values are $18.9 \mathrm{mag} / \operatorname{arcsec}^{2}$ and no change. Marco et al. (2015) measured light pollution in Valencia (population 2.5 mil- 
Table 1: Data on light pollution in several large towns around the world gathered from available literature. The sky brightness values are in mag/arcsec ${ }^{2}$.

\begin{tabular}{|c|c|c|c|c|c|c|}
\hline Town & Pop. (mio) & Year & Mean & Clear & Cloudy & Reference \\
\hline Zagreb & 0.8 & $2012-17$ & 16.9 & 18.2 & 15.0 & Andreić, 2018 \\
\hline Merenje & & 2014-17 & 18.9 & 20.3 & 18.2 & This work \\
\hline Vienna & 1.7 & 2014 & & 19.1 & 16.3 & Puschnig et al., 2014 \\
\hline Hong-Kong & 7.1 & 2014 & 16.8 & & & Pun et al., 2014 \\
\hline \multirow{2}{*}{ Seoul } & 9.8 & 2009 & & 16.3 & & \multirow{4}{*}{ Yu et al., 2015} \\
\hline & & 2014 & & 16.5 & & \\
\hline \multirow{2}{*}{$50 \mathrm{~km}$ from Seoul } & & 2009 & & 20.1 & & \\
\hline & & 2014 & & 20.6 & & \\
\hline Valencia & 2.5 & 2014 & & 17.5 & 14.5 & Marco et al., 2015 \\
\hline Krakow & 0.8 & 2014 & & 17.8 & & Ścięzor and Kubala, 2014 \\
\hline
\end{tabular}

lion) and its surroundings in 2014, and concluded that the night sky brightness is around $17.5 \mathrm{mag} / \mathrm{arcsec}^{2}$ for clear sky conditions, with an increase of more than 3 magnitudes in cloudy conditions. Ścięzor and Kubala (2014) analyzed the relationship between aerosol concentration and light pollution based on night sky brightness measurements taken at several places in Krakow, Poland (population 778000 ). This data can be compared with the aforementioned results. Krakow is of interest as it is a European city very similar to Zagreb (population 790 000). The obtained values for Krakow are between 17.1 and $18.5 \mathrm{mag} / \operatorname{arcsec}^{2}$, averaging at about $17.8 \mathrm{mag} /$ $\operatorname{arcsec}^{2}$ for clear sky conditions.

The results of light pollution monitoring above Zagreb, Croatia, were discussed for the first time by Sharma et al. (2015) for a short period in 2010 - 2011 and in near infrared (NIR) for Croatian sites, including Zagreb by Andreić et al. (2012). A longer dataset for the period 2012 - 2017 was analyzed in a recent article by one of the authors (Andreić, 2018). It was shown that night sky brightness in this period was more or less constant, however it was at a very high level of about $18.2 \mathrm{mag} / \mathrm{arcsec}^{2}$ for clear sky conditions. The question that was raised, but remained unanswered by that article, is whether or not the night sky brightness is also constant in the suburbs of Zagreb and in the nearby rural area. This is due to the lack of any reliable long-term measurements there. In Table 1 we summarize the results of all above mentioned studies, including the ones cited by Andreić (2018).

In the meantime, we obtained additional data that could be consulted. This data was gathered at the site of a private observatory located about $20 \mathrm{~km} \mathrm{NW}$ from Zagreb in a small village called Merenje. The data available covers the period from 2014 to 2017. In this article, we are analyzing if the night sky brightness is also constant at the Merenje site.

\section{Methods and data}

The measurements at the RGN site were taken by a single automatic SQM-LE device on the roof of the building of the Faculty of Mining, Geology and Petroleum Engineering in Zagreb $\left(45.8070^{\circ} \mathrm{N}, 15.9641^{\circ} \mathrm{E}\right.$, approx. $150 \mathrm{~m}$ above sea level). The building itself is near the town center, about $1.2 \mathrm{~km}$ air-line from the $\mathrm{Za}$ greb main square. The instrument looks straight into the zenith, and the direct influence of streetlights is negligible due to the large height of the building (see Figure 1, left). The Merenje observatory $\left(45.9000^{\circ} \mathrm{N}, 15.7833^{\circ} \mathrm{E}\right.$, approx. $190 \mathrm{~m}$ above sea level) is located about $20 \mathrm{~km}$ NW from Zagreb. These measurements started in 2014, and the instrument used is the SQM-LU-DL, an autonomous version of the SQM-L device (see Figure 1, right). The only difference in comparison to the SQM-LE used at the RGN site is in the way data is collected. The SQMLE is computer controlled and sends the data at request to a remote computer that archives the data. The SQMLU-DL is autonomous, and stores the measured data in the device itself. To access the data, the device must be connected to a computer periodically. In addition, the power source (batteries or accumulators) have to be taken care of regularly.

To make an unbiased comparison, the RGN dataset was limited to the period $2014-2017$ for which the Merenje data exists, and accordingly recalculated. The analyzing procedures were kept the same as in the previous article (Andreić, 2018) so we will just repeat a short description of them. Raw data from the SQM's are stored as text files. The data from these files were processed by a set of a few small programs that first eliminated all measurements taken during daylight. They are meaningless as the SQM is in saturation. After that, the time stamps of individual measurements were converted into a much more usable ordinal number of the measurement in question, keeping the information regarding the date of measurements along it. The data is then plotted using Excel. However, the graphs (or tables) of daily data were hard to analyze due to large oscillations of initial values, resulting in the statistical analysis that produced much more manageable sets of daily and monthly minima, maxima and mean values of night sky brightness. These results were again processed in Excel resulting in graphs 


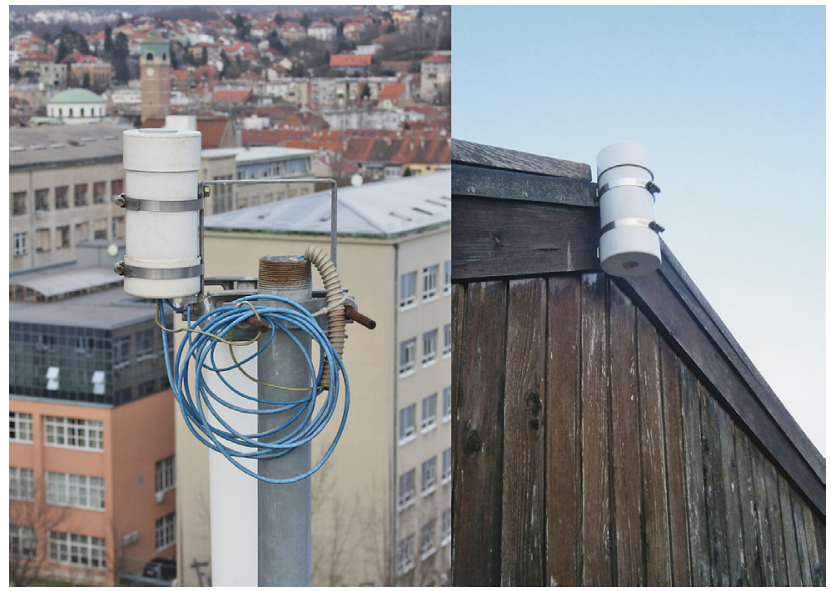

Figure 1: Left: The SQM-LE instrument at the RGN site is inside a protective box (white) mounted on the roof of the faculty building. Right: The SQM-LU-DL instrument at the Merenje site is also inside a protective box mounted on the roof of a small shed in the countryside. Both instruments have a clear zenithal area.

and conclusions about light pollution behavior. This time, nightly data is gathered into seasonal datasets which enables us to check for seasonal variations among them. The seasonal data is plotted as cumulative graphs of measured sky brightness and as histograms.

Last, but not least, both the manufacturer (Unihedron2, 2020) and the independent analyses of the instrument accuracy (Cinzano, 2005; Schnitt et al., 2013) lead to the same conclusion that the accuracy of the SQM is of the order of $10 \%$ in a linear scale, or about 0.1 $\mathrm{mag} / \mathrm{arcsec}^{2}$ in astronomical units.

\section{Results and discussion}

First of all, the question arises if, and to what extent, the meteorological conditions at both sites are related to each other. Medvednica Mountain passes between them, so direct visibility is not possible. The main optical effect of the Medvednica Mountain, as observed from the Merenje site, is shadowing the direct lights from the whole city of Zagreb, so that the lowest part of the atmosphere above Merenje is not light-polluted by Zagreb. Zagreb is the capital city of Croatia, with about 800000 inhabitants (according to the last census in 2011). Looking from the Merenje site towards Zagreb, Medvednica Mountain rises rapidly, starting at the lineof-sight azimuth of about $160^{\circ}$, passing the RGN direction at the azimuth of $140^{\circ}$ with a height of about $430 \mathrm{~m}$ to about $1000 \mathrm{~m}$ at its highest peak at the azimuth of $116^{\circ}$. After that, Medvednica Mountain decreases in height slowly, passing $500 \mathrm{~m}$ at the azimuth of about $90^{\circ}$, with its extreme eastern point lying at the azimuth of $80^{\circ}$. The whole city of Zagreb is hidden behind the mountain. Accordingly, the lower parts of the atmosphere between Medvednica Mountain and the Merenje site are protected from the direct lights of Zagreb, effectively reducing the contribution of Zagreb to light pollution there. However, Zagreb lights illuminate the atmosphere above about $1000 \mathrm{~m}$, thus the Merenje site is still under the light pollution dome of Zagreb. On the other side of Merenje, and around it, only smaller settlements exist, a lot of them hidden by hills which are abundant in the whole area around Merenje. However, the whole area is quite densely populated and the combined effect

\section{Merenje-RGN direct comparison}

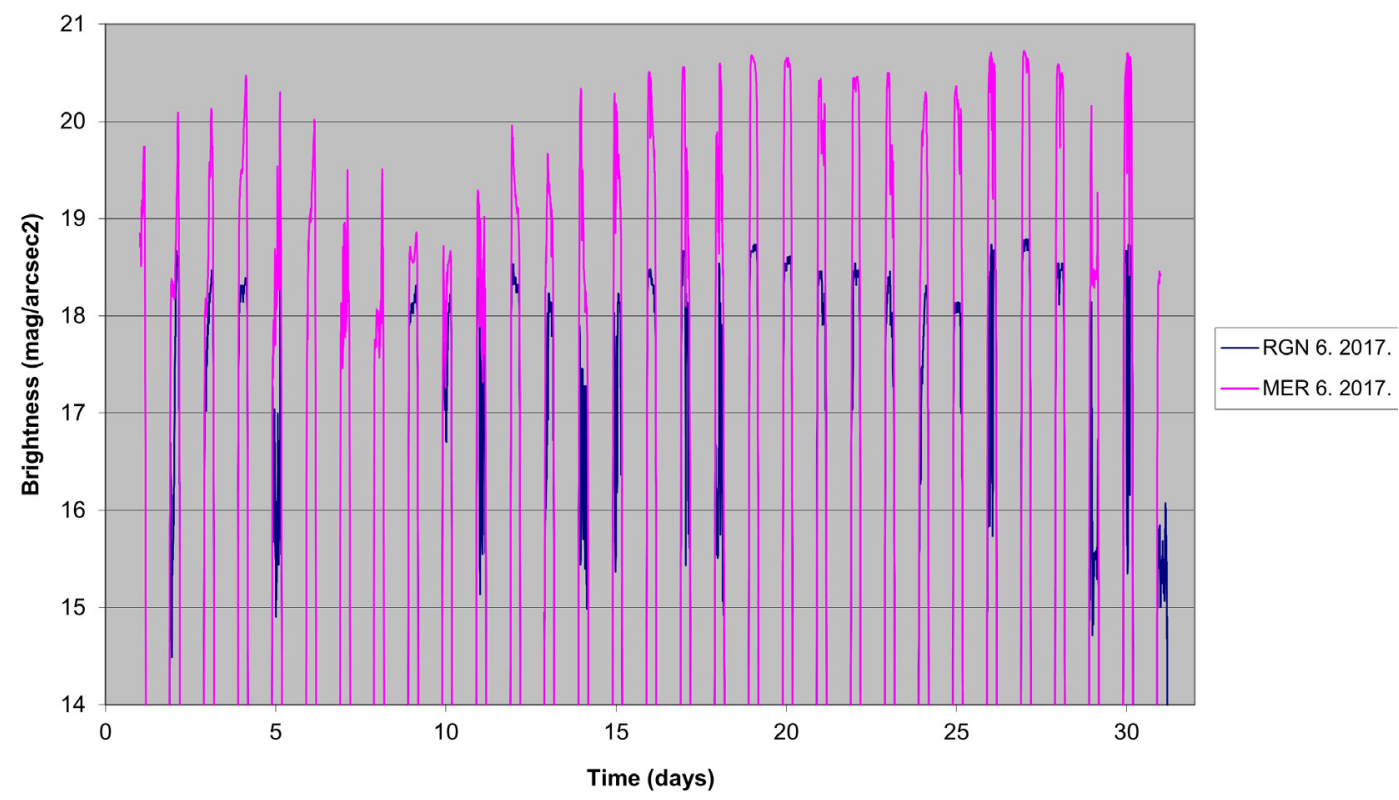

Figure 2: A comparison of night sky brightness measurements at RGN and Merenje sites taken in June 2017. Apart from the difference in overall brightness (the Merenje site is darker by about 1.7 mag/ $\left.\operatorname{arcsec}^{2}\right)$, the sky brightness at both sites follows a very similar pattern most of the time. 


\section{Merenje-RGN direct comparison}

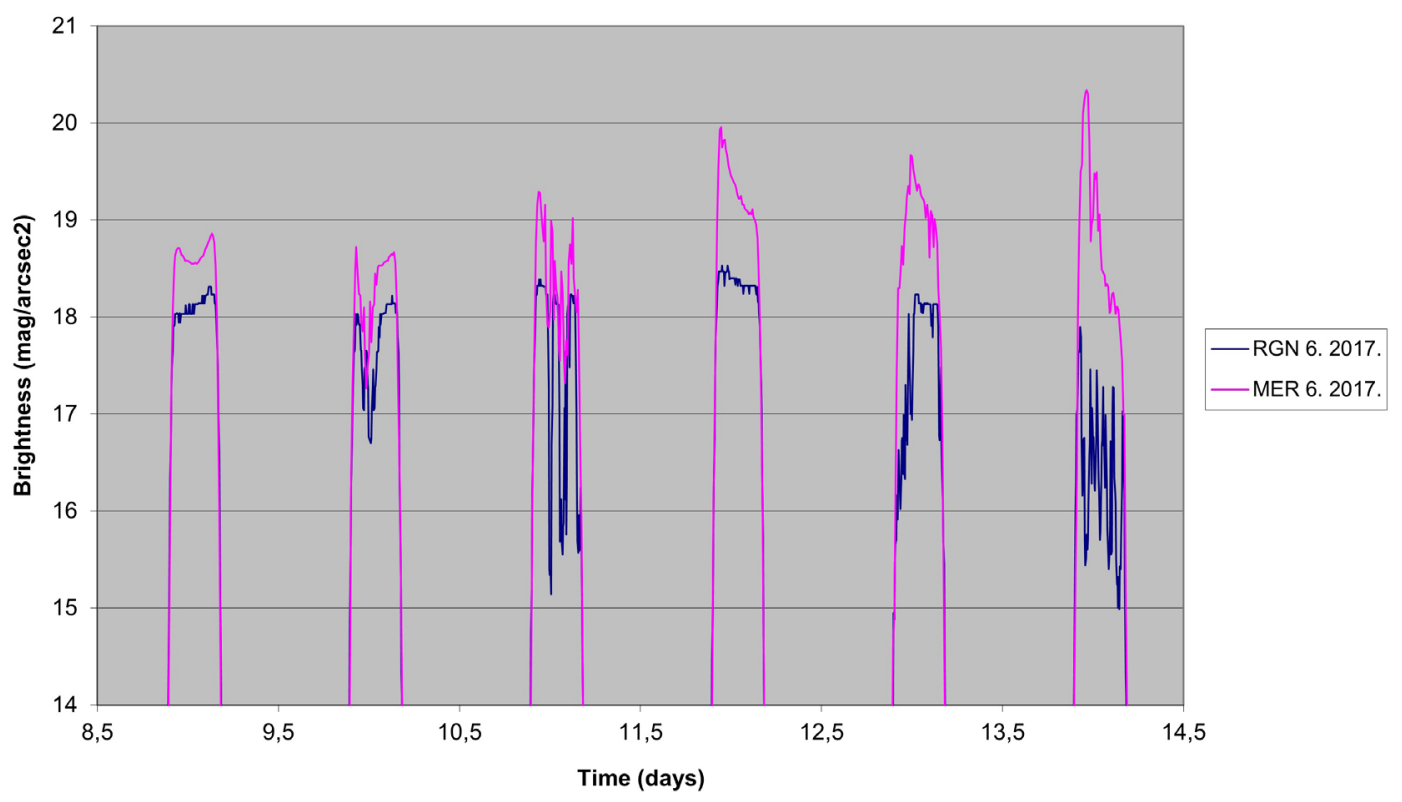

Figure 3: An enlarged part of the graph in Figure 2 showing night sky brightness patterns at both sites in more detail. In most cases, the patterns are very similar. A more pronounced difference is evident in the last night (14-15th) on the graph. Note that the influence of the Moon is more pronounced at the Merenje site, as the light pollution there is lower, thus the moonlight alone makes a larger contribution to the night sky brightness, when the Moon is up. In this case, the Moon was up almost the whole night, as the Moon was full on June 9 th.

Table 2: Yearly statistics of nightly minima, maxima and average values of sky brightness and its nightly changes (variations) for years 2014 to 2017, for both sites. All brightness values are expressed in mag/arcsec ${ }^{2}$. The last two rows give mean values for the whole period of measurements (2014-2017).

\begin{tabular}{|c|c|c|c|c|c|c|c|c|c|}
\hline \multirow{2}{*}{\multicolumn{2}{|c|}{ Year }} & \multicolumn{3}{|c|}{ Sky brightness } & \multicolumn{3}{|c|}{ Nightly variations } & \multirow{3}{*}{$\begin{array}{c}\begin{array}{c}\text { Number } \\
\text { of nights }\end{array} \\
244\end{array}$} & \multirow{3}{*}{$\begin{array}{c}\begin{array}{c}\text { Missing } \\
\text { nights }\end{array} \\
121\end{array}$} \\
\hline & & \multirow{2}{*}{$\begin{array}{l}\max . \\
13.63\end{array}$} & \multirow{2}{*}{$\begin{array}{c}\text { min. } \\
18.89\end{array}$} & \multirow{2}{*}{$\begin{array}{c}\text { mean } \\
16.66\end{array}$} & \multirow{2}{*}{$\begin{array}{c}\text { min. } \\
0.06\end{array}$} & \multirow{2}{*}{$\begin{array}{c}\text { max. } \\
3.87\end{array}$} & \multirow{2}{*}{$\begin{array}{c}\text { mean } \\
1.94\end{array}$} & & \\
\hline & RGN & & & & & & & & \\
\hline 2014 & MER & 15.67 & 20.66 & 18.85 & 0.31 & 3.63 & 1.59 & 176 & 189 \\
\hline \multirow{2}{*}{2015} & RGN & 13.27 & 18.84 & 16.90 & 0.08 & 4.33 & 1.78 & 161 & 204 \\
\hline & MER & 14.63 & 20.67 & 18.92 & 0.29 & 4.76 & 1.54 & 267 & 98 \\
\hline \multirow{2}{*}{2016} & RGN & 14.20 & 18.94 & 16.99 & 0.06 & 4.27 & 1.83 & 324 & 42 \\
\hline & MER & 14.97 & 20.82 & 18.79 & 0.23 & 3.63 & 1.65 & 345 & 21 \\
\hline \multirow{2}{*}{2017} & RGN & 14.15 & 19.03 & 17.08 & 0.07 & 4.20 & 1.88 & 227 & 138 \\
\hline & MER & 15.39 & 20.90 & 18.88 & 0.12 & 3.61 & 1.58 & 309 & 56 \\
\hline \multirow{2}{*}{ mean } & RGN & 13.81 & 18.93 & 16.91 & 0.07 & 4.17 & 1.86 & 239 & 126 \\
\hline & MER & 15.17 & 20.76 & 18.86 & 0.24 & 3.91 & 1.59 & 274 & 91 \\
\hline
\end{tabular}

of these settlements produces some local light pollution and is often additionally seen as smaller light pollution domes near the horizon.

Another effect of Medvednica Mountain is its influence on local meteorological conditions. Often, the weather is very similar at both sites, but sometimes significant differences can occur. According to Köppens climate classification, this area has a temperate humid climate with a warm summer $(\mathrm{Cfb})$ (Zaninović et al., 2008). This type of climate is characterized by a diver- sity of weather situations. During the winter, a stationary anticyclonic weather type prevails, with foggy weather or low clouds. During the spring, faster cyclonal types of weather become frequent, which leads to frequent and rapid changes in weather. In the summer, the zero-pressure gradient field is often interrupted by a cold front of cold air from the Atlantic, with a strong air mixing, strong winds, thunder and heavy rainfall from dense clouds with vertical development. In autumn, there are frequent periods of calm anticyclonic weather, but also 
LP Merenje 2014
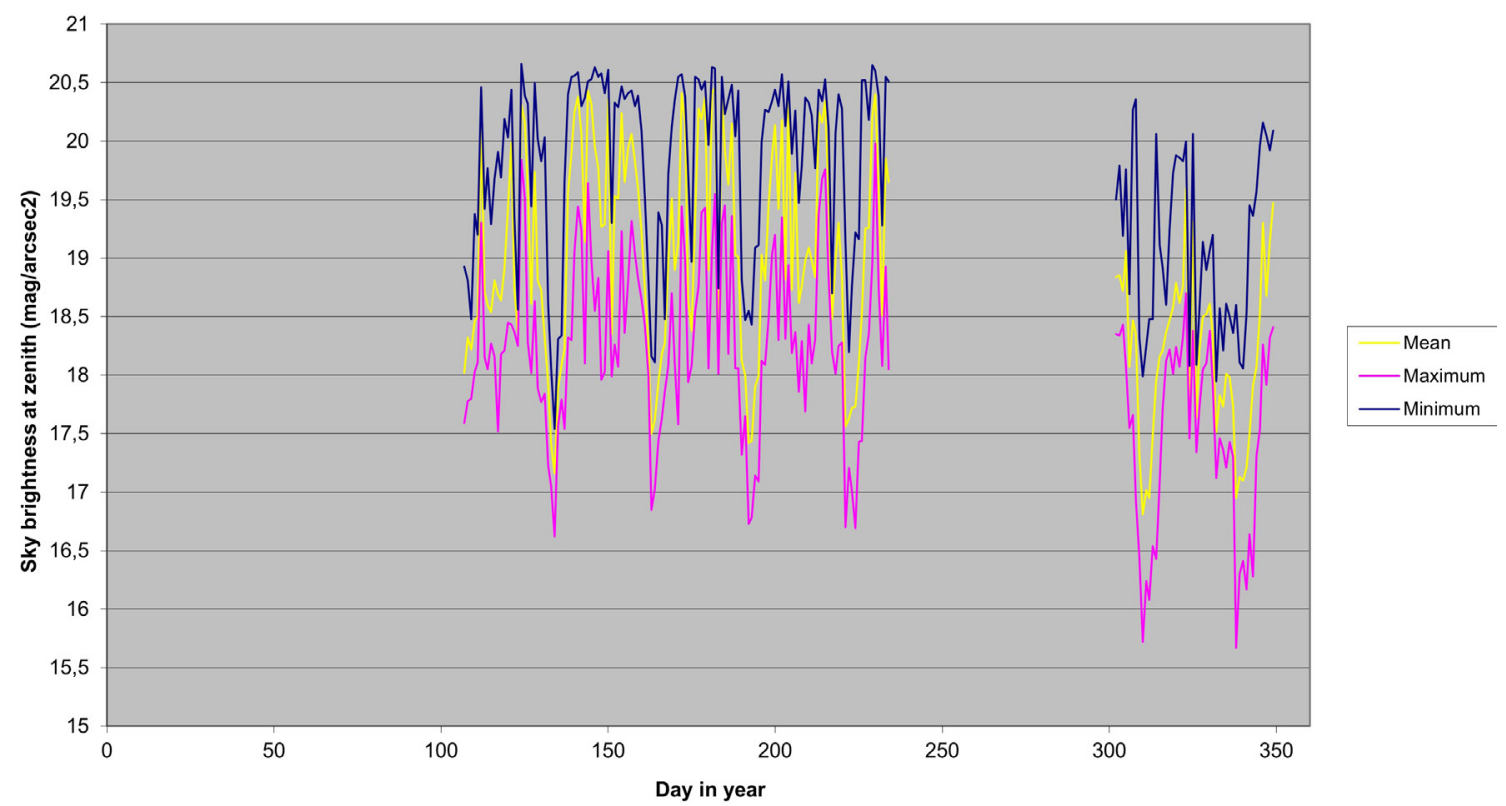

LP Merenje 2015

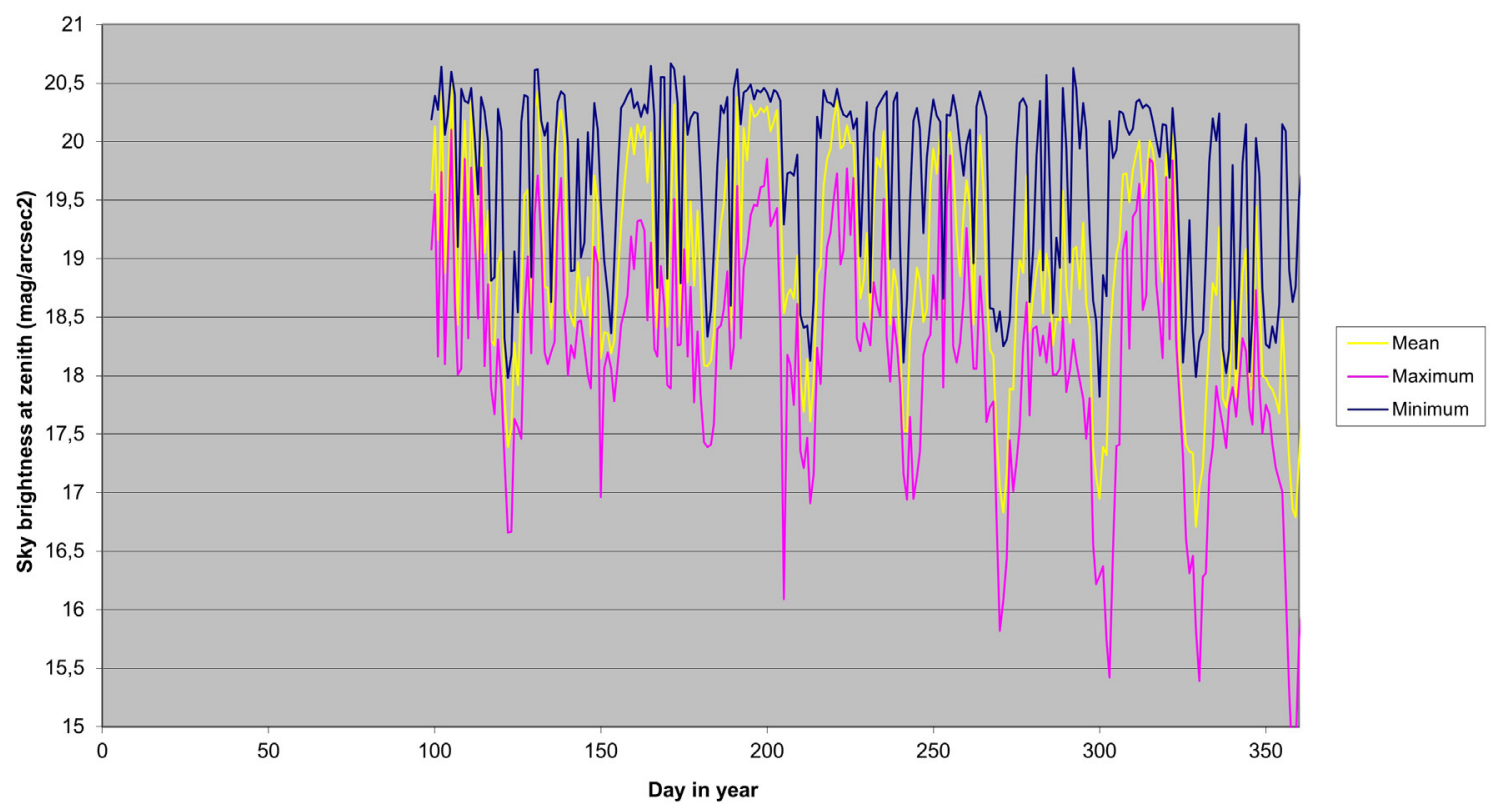

Figure 4: The nightly minima, maxima and average values of Merenje sky brightness for years 2014 and 2015

rainy days when cyclones cross the area. Anticyclonic weather in the early fall is characterized by warm and sunny days and cool nights with heavy dew and low fog strips near rivers and streams. In the late fall, anticyclonic weather is cold, foggy and gloomy, with short sunny periods. The local climate modifier is an orography, which leads to the intensification of short-term heavy precipitation on the windward side of the orographic barrier or the appearance of a precipitation shadow on the leeward side. Medvednica Mountain affects the eastern part of Zagreb in this way (Zaninović et al., 2008).
Locally, the major weather phenomenon in this area affecting light pollution is fog. In this area, it occurs frequently in autumn and spring, less frequently in winter and is absent in summer. Also, Zagreb is large enough to influence the local meteorological conditions, often resulting in higher local temperatures and less fog than in the surrounding area, a fact that should also be considered when comparing the RGN and Merenje sites. From the side of light pollution, the most important thing to keep in mind is the passage of clouds and the periods of clear/cloudy skies related to it, which can be different, or 
LP Merenje 2016

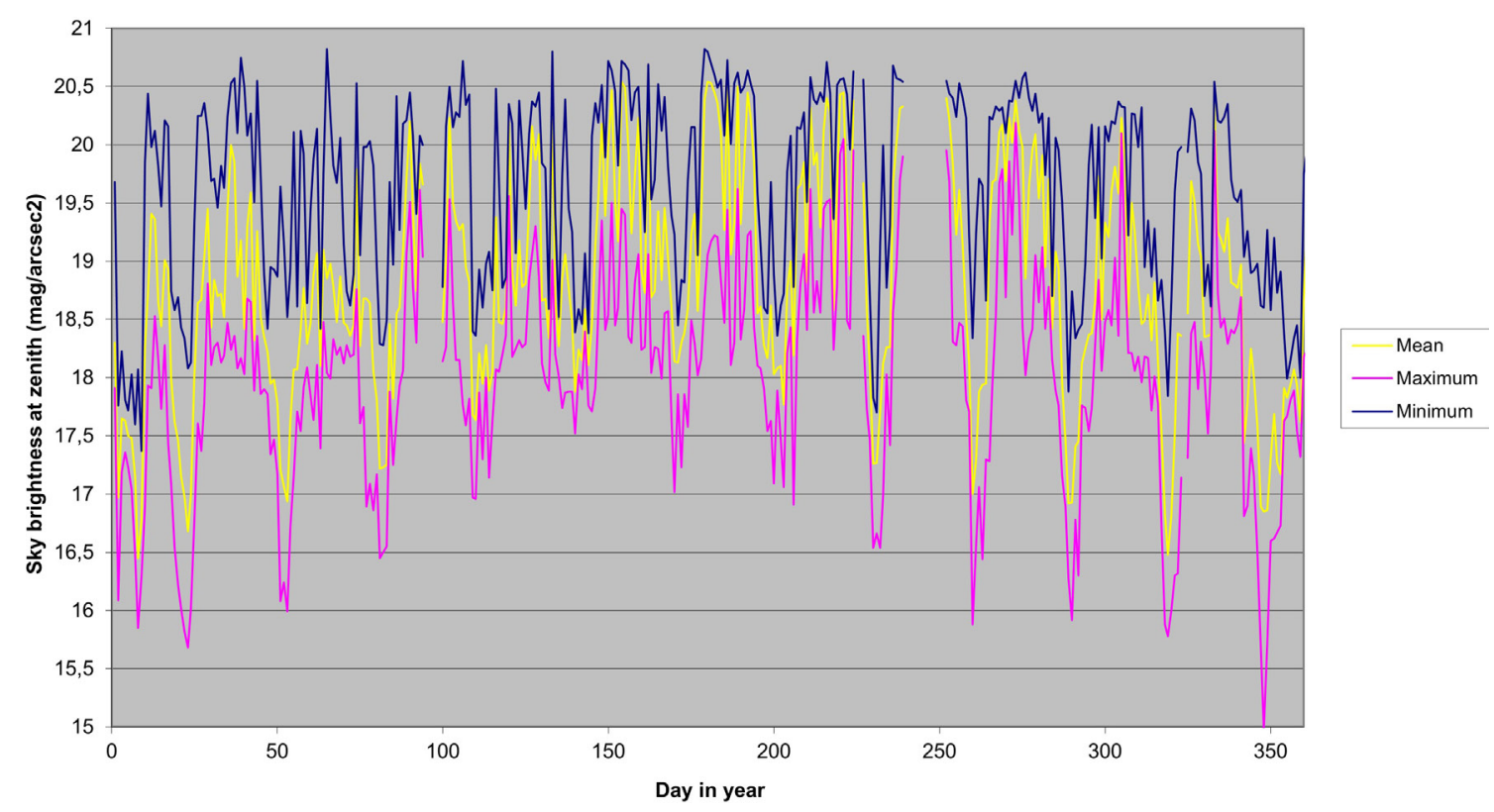

LP Merenje 2017

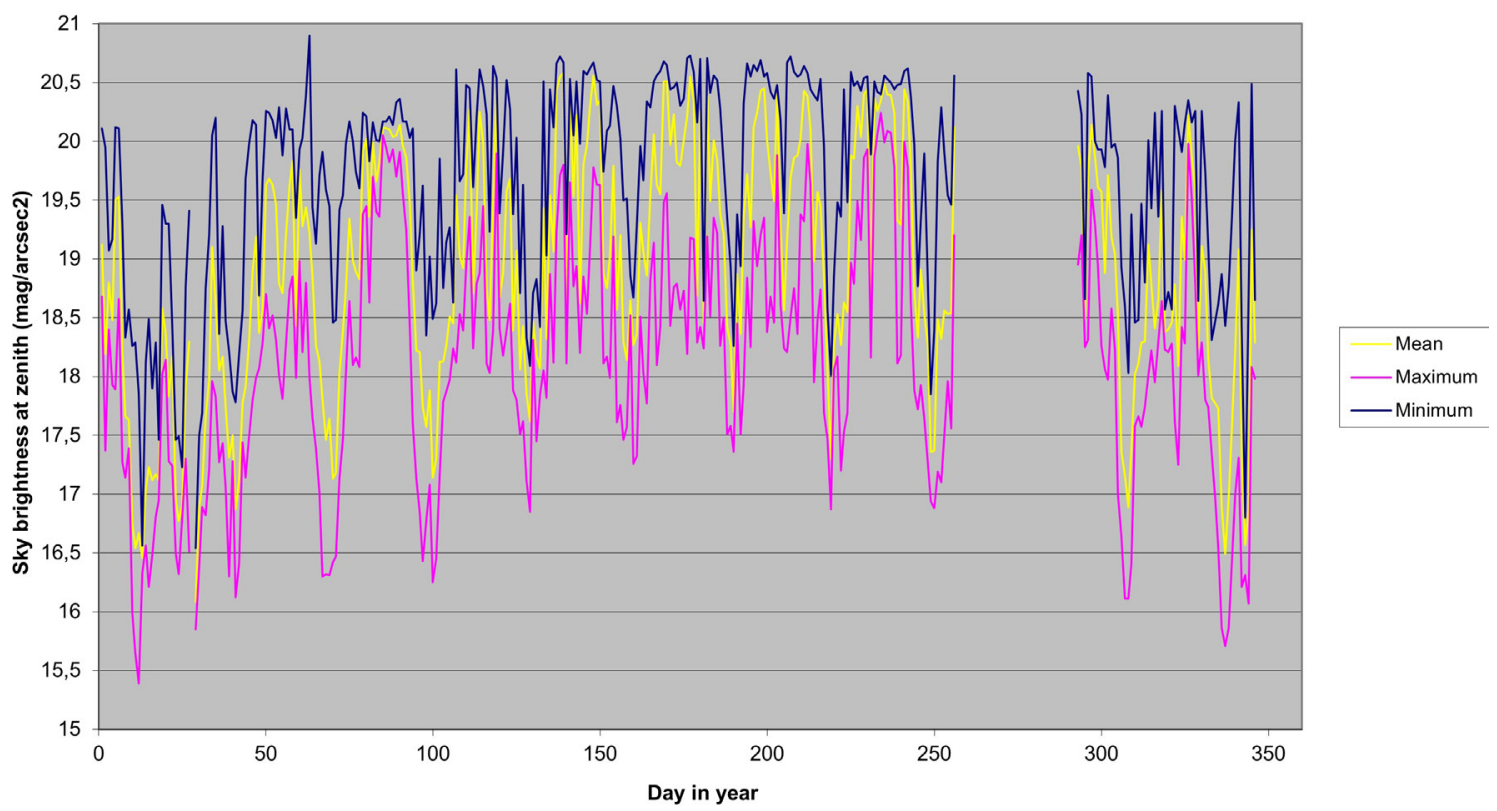

Figure 5: The nightly minima, maxima and average values of Merenje sky brightness for years 2016 and 2017

just shifted in time. We did not perform a thorough analysis of this effect, limiting ourselves to comparing raw data, which led to the conclusion that the sky brightness at both sites follows very similar patterns most of the time, the Merenje site being darker by about $1.7 \mathrm{mag} /$ $\operatorname{arcsec}^{2}$ most of the time. This fact is illustrated in Figure $\mathbf{2}$ and Figure 3, where a short time series of LP measurements taken at both sites (30 and 5 days) are compared. The data for the whole period shows a very similar behavior, so the example on Figure 2 and Figure 3 suffices to illustrate it.
Table 2 summarizes yearly minima, maxima and average values of measured sky brightness followed by the nightly variation of these values (also expressed as minimal, maximal and mean values observed over the year), together with information on the number of nights that provided the data for the statistics. In the period between January 2014 and December 2017, about half (53\%) of the RGN data and about a third (33\%) of the Merenje data was lost for different reasons. The most problematic in this aspect are years 2015 for RGN and 2014 for Merenje. Still, the remaining data is sufficient for a com- 
Cumulative probability, Merenje 2014-2017

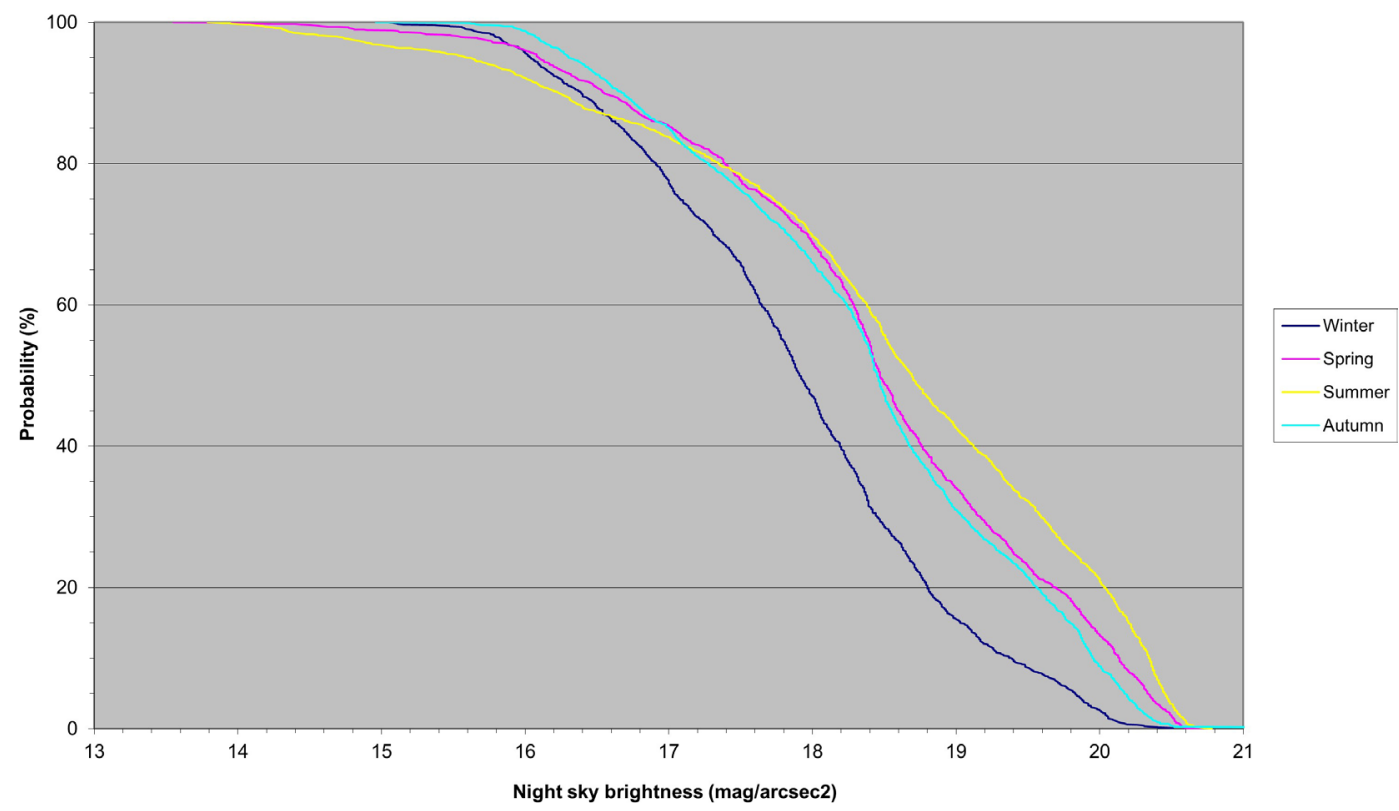

Figure 6: The average cumulative probability that the night sky brightness at the Merenje site will be darker than a given value, derived from all measurements available during the 2014-2017 period

Merenje sky brightness histogram 2014-2017

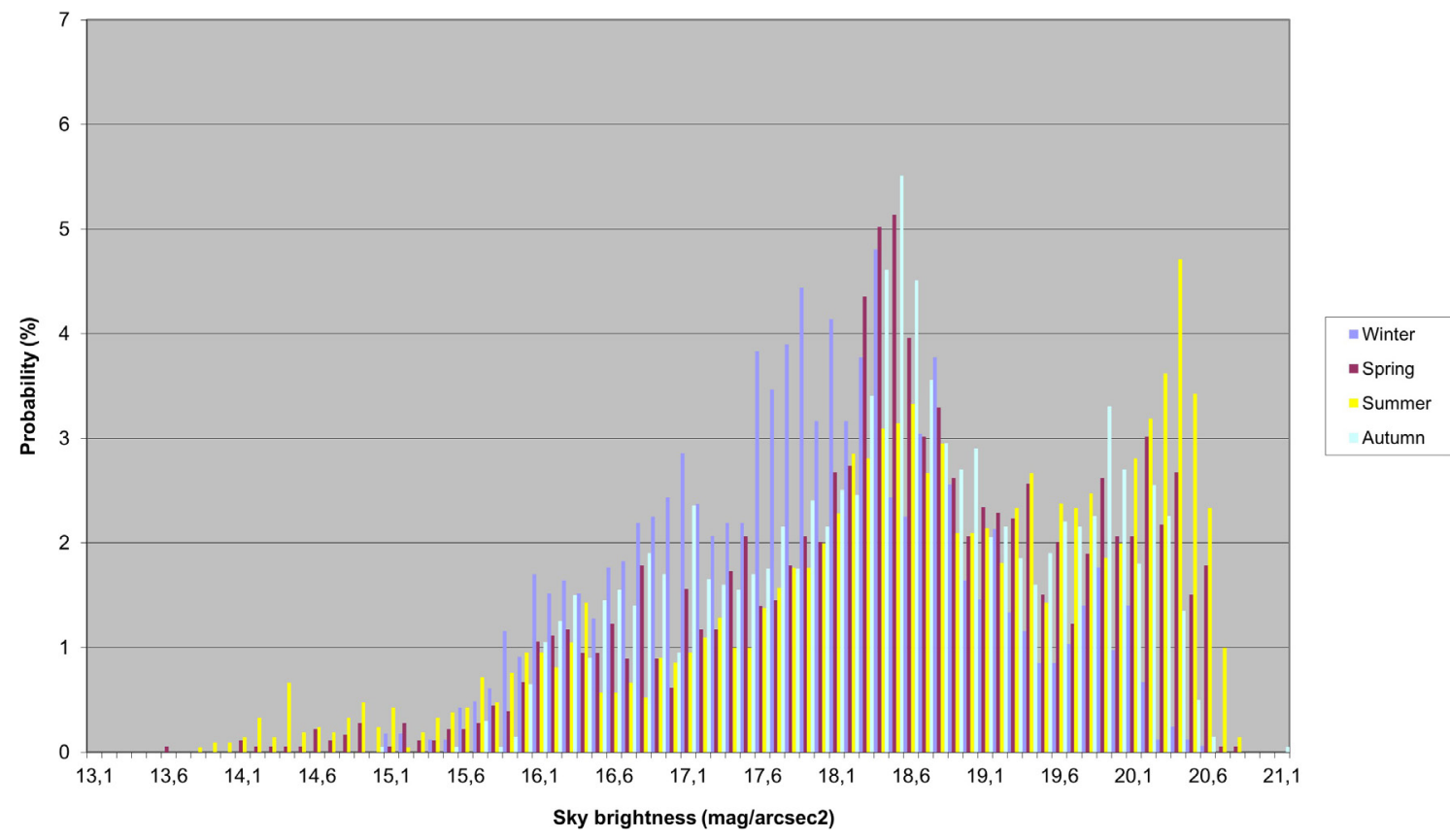

Figure 7: A histogram of the night sky brightness at the Merenje site derived from all measurements available during the 2014-2017 period. The histogram is created for meteorological seasons and should be taken as an average of seasonal behavior during the period.

parison, and summary statistics do not show any significant differences from year to year that could be related to the missing data.

The main conclusion that can be drawn from Table 2 is that the average level of light pollution at both sites does not change significantly during the monitoring period (2014 to 2017) (Andreić, 2018). At least for the part of Croatia that is protected by the shadow of Medvednica Mountain, this is good news. The situation in the opposite direction from the town of Zagreb cannot be determined 
Cumulative probability, Merenje-RGN, winter 2014-2017

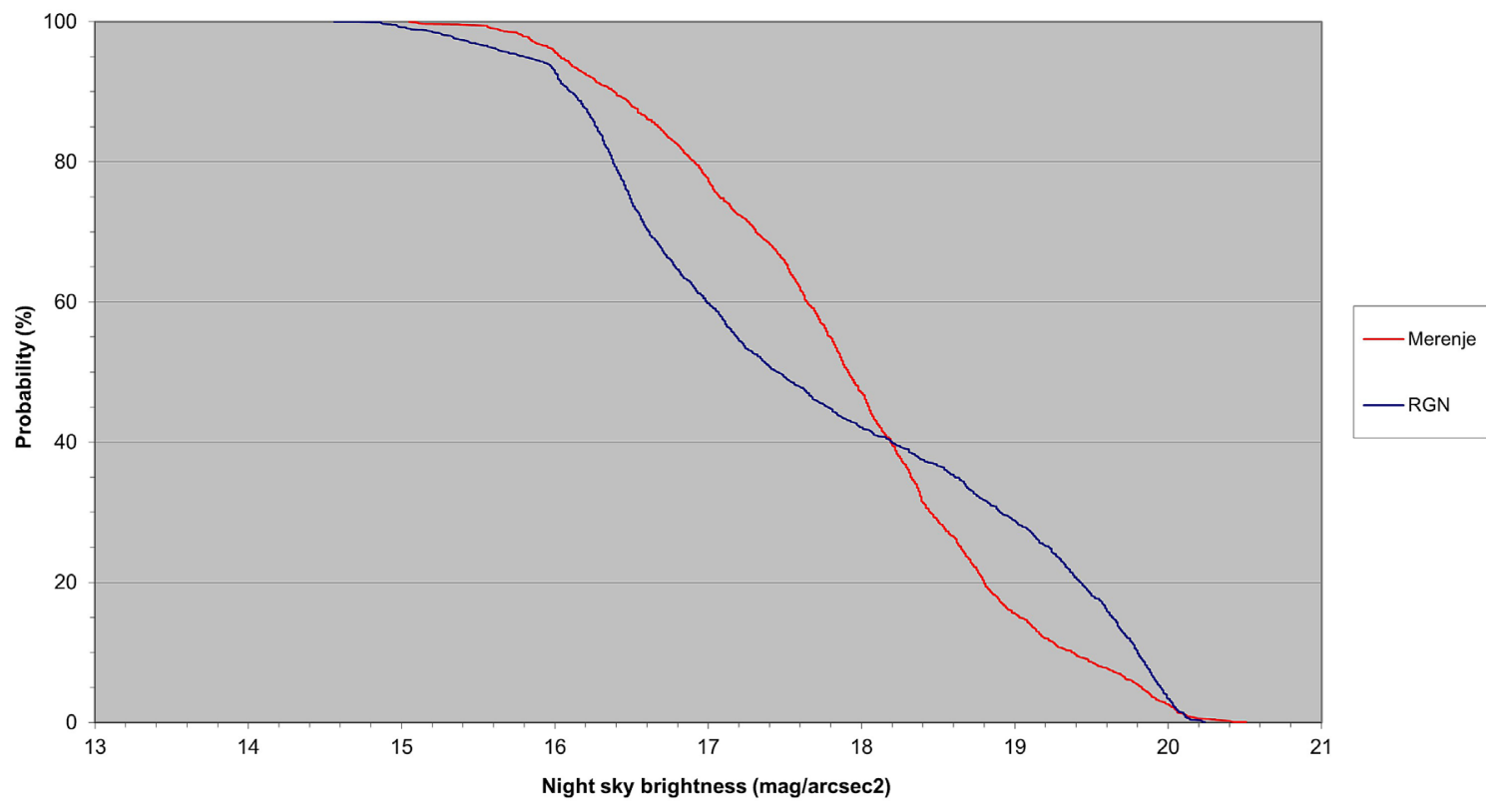

Cumulative probability, Merenje-RGN, spring 2014-2017

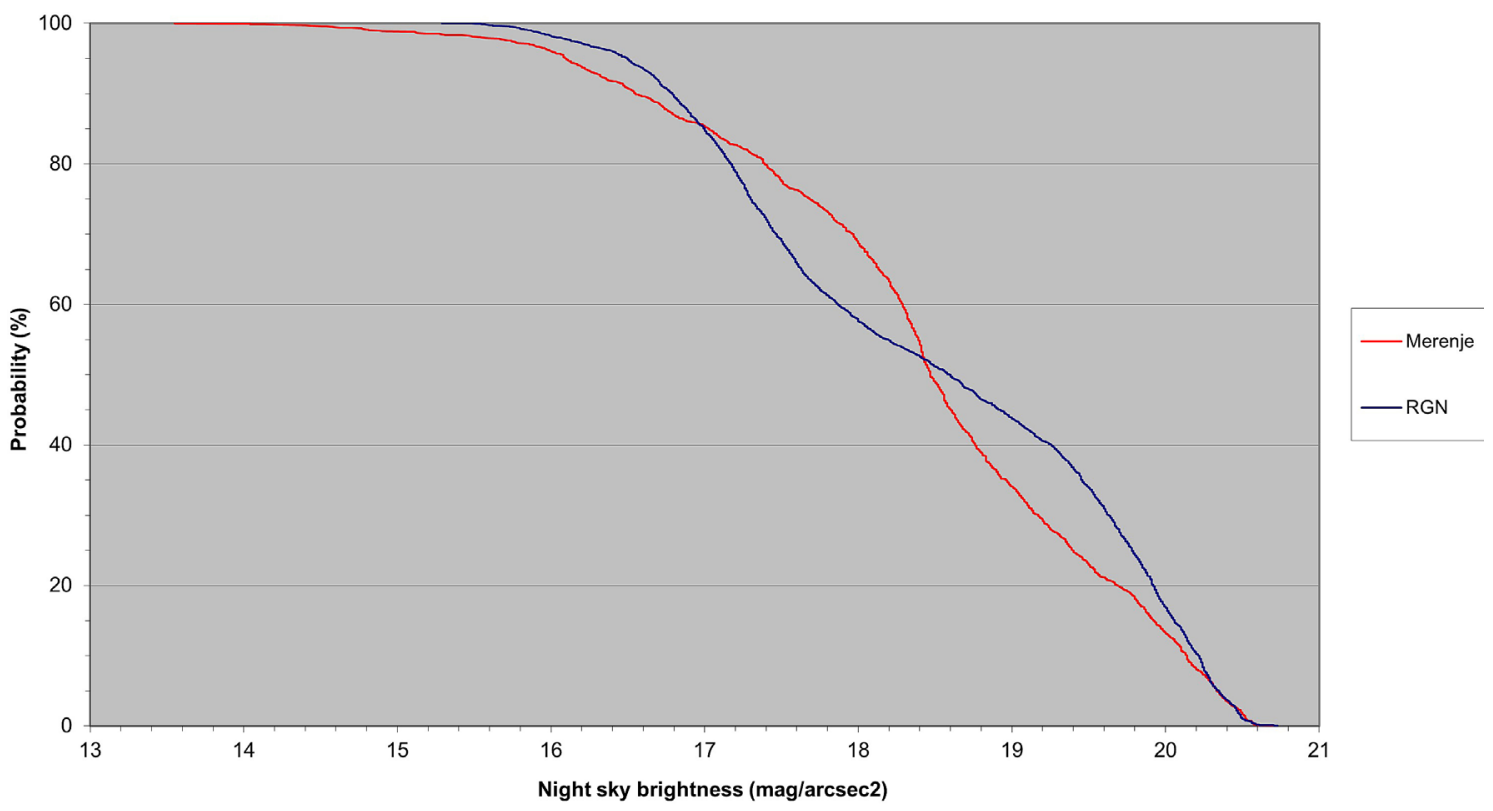

Figure 8: A comparison of the average cumulative probabilities for the RGN and Merenje sites for winters (top) and springs (bottom) 2014-2017. For ease of comparison, the RGN curve was shifted to the right for $1.55 \mathrm{mag}^{-\mathrm{arcsec}^{2}}$ (winter) and $1.90 \mathrm{mag} / \operatorname{arcsec}^{2}$ (spring).

from this work, as this would require at least one monitoring site south of the town. The situation there can be much different as this is a rather flat area into which Zagreb expands a lot more than to the north, where growth is prevented by the Medvednica Mountain, the largest part of which is a protected nature park (ZZPUZG, 2019).

The minimal and maximal values of the night sky brightness reported in Table 2 should be taken as indicators only, as a single data point produces these values so they are not indicative of general trends in the light pol- lution behavior. The methods for interpreting such measurements are still in the development stage and no general consensus about their interpretation exists. On the other hand, the mean values are a solid representation of actual light pollution levels for the corresponding night as they are calculated from at least several dozen individual measurements (in the shortest summer nights). The main conclusion that is drawn from these mean values is, as in Andreić (2018), that light pollution levels did not change significantly in the monitoring period. 
Cumulative probability, Merenje-RGN, summer 2014-2017

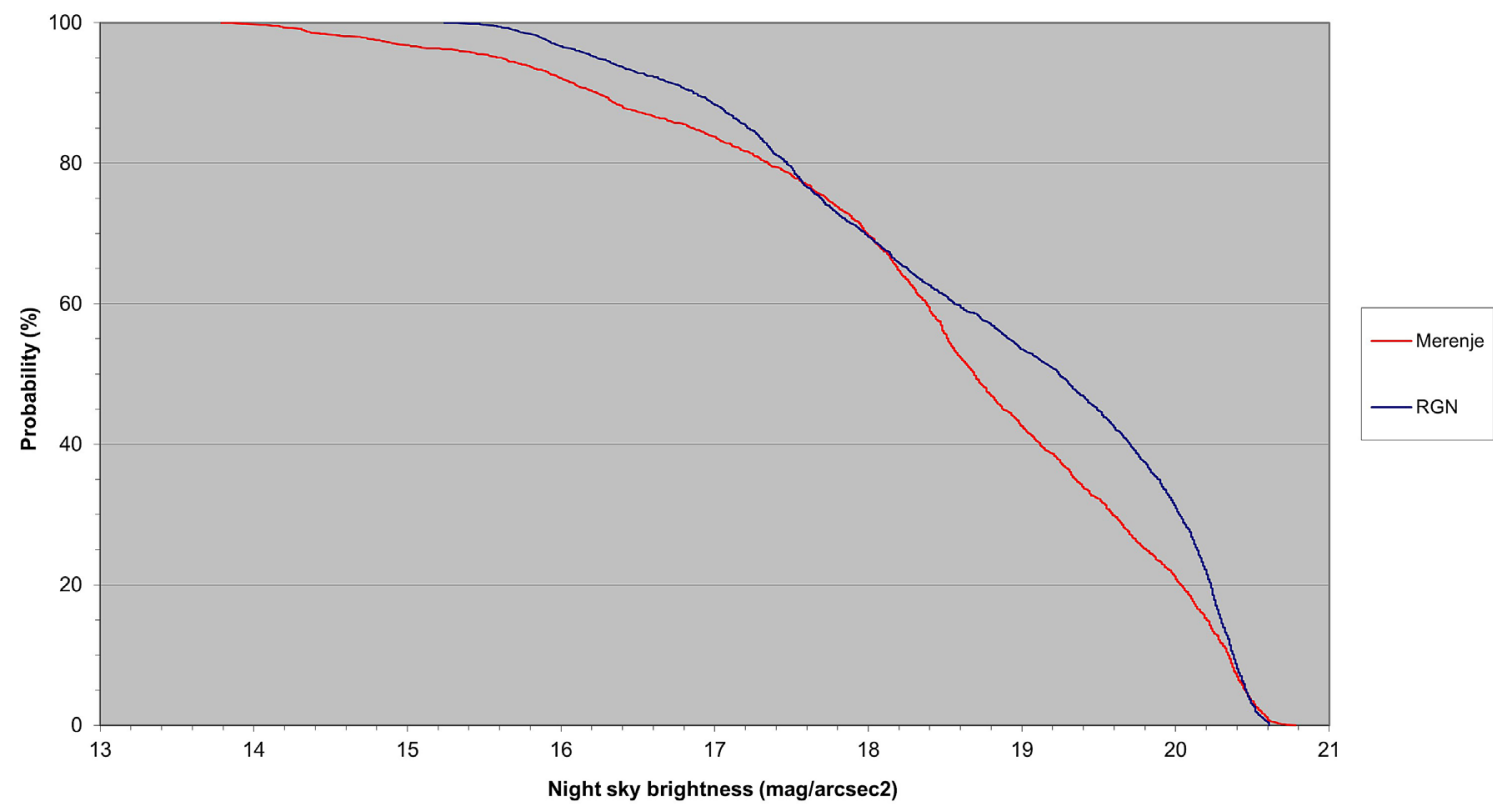

Cumulative probability, Merenje-RGN, autumn 2014-2017

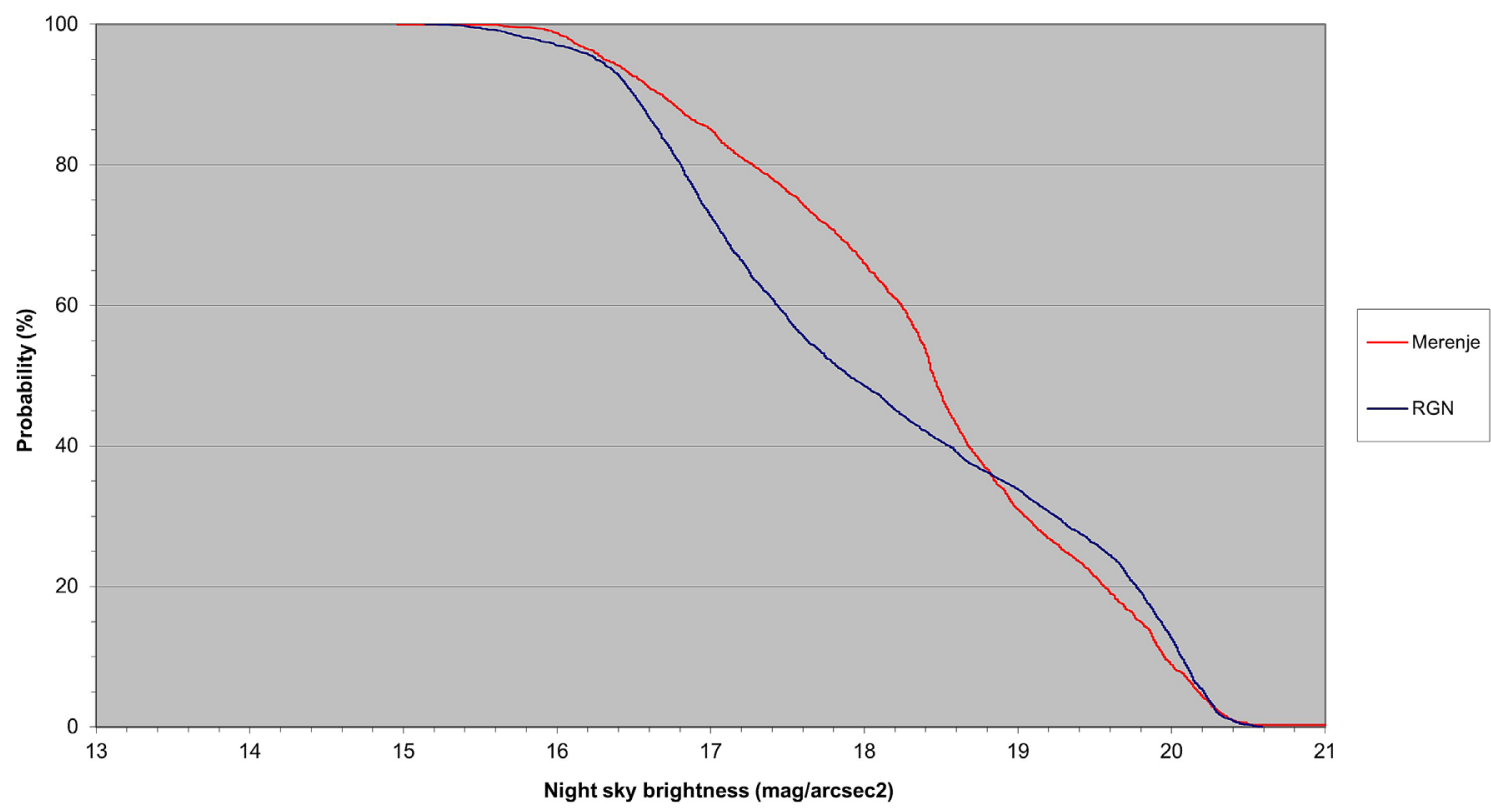

Figure 9: A comparison of the average cumulative probabilities for the RGN and Merenje sites for summers (top) and autumns (bottom) 2014 -2017. For ease of comparison, the RGN curve was shifted to the right for $1.80 \mathrm{mag} / \mathrm{arcsec}^{2}$ (spring) and $1.65 \mathrm{mag} / \operatorname{arcsec}^{2}$ (autumn).

As was the case with the RGN site, nightly minima, maxima and mean values of the sky brightness for the Merenje site (see Figure 4 and Figure 5) change considerably on a nightly basis. The corresponding graphs for the RGN site can be found in Andreić (2018, Figure 7 and 8). The main cause for these variations at both locations are changes in meteorological conditions (clouds, fog, and atmospheric transparency) that reflect themselves in the amount of light pollution caused. The rapid changes that happen during one night are considerable, often being greater than two or even three magnitudes. Even the mean variations at the Merenje site are considerable; being between 1.5 and $1.7 \mathrm{mag} / \operatorname{arcsec}^{2}$ from year to year (expressed as yearly averages). Compared to the RGN site, mean variations at the Merenje site are somewhat dimmer, by about $0.2 \mathrm{mag} / \mathrm{arcsec}^{2}$.

Again, as was the case with the RGN site, due to these rapid variations, Figure 4 and Figure 5 are difficult to interpret. Thus, the most important statistical data about light pollution at both sites are gathered in Table 2, and 
presented as cumulative probabilities in Figure 6 and as histograms in Figure 7.

The seasonal cumulative probabilities curves in Figure 6 give the probability that at any given moment (at night of course) the sky brightness will be smaller (or larger) than a certain value. The meteorological seasons are used throughout this text. The same data is presented in Figure 7 as a histogram. Please take into account that seasonal variations are quite large from year to year. The histogram bins are $0.1 \mathrm{mag} / \operatorname{arcsec}^{2}$ in width. Both figures confirm that spring and summer provide better observing conditions (less light pollution) than autumn and winter. The histogram in Figure 7 confirms, as was found for the RGN site before, that the brightness values clutter around two peaks, one at about $18.2 \mathrm{mag} / \mathrm{arcsec}^{2}$ and the other at about $20.3 \mathrm{mag} / \mathrm{arcsec}^{2}$, both showing a tendency to move slightly toward lower brightness values in spring and summer. The two peaks are explained as before: clear nights result in lower sky brightness, the values forming the second peak, and the cloudy nights result in much larger sky brightness which forms the first peak. The difference between them is about 2.1 magnitudes, compared to about 3 magnitudes for the RGN site, showing that the larger light pollution at the latter is more enhanced during cloudy conditions. The slight drift toward lower brightness in spring/summer is the result of the dryer and more transparent atmosphere during this period of the year.

Last, but not least, the seasonal cumulative probabilities for both sites (see Figure 8 and Figure 9) are compared with each other. For ease of comparison, the RGN curves are shifted to the right to compensate for different levels of light pollution at the two sites. The exact amount of shift is stated under each figure. This comparison shows that, generally, clouds enhance the night sky brightness a lot more in Zagreb than in the surrounding area, confirming that the stronger light pollution is much more strongly enhanced by clouds. Apart from that, the clear sky parts of the curves (the right-bottom part of the curves) show very similar shapes. It is actually possible to match them better, at the cost of separating the upper parts of them more. This confirms that clear sky conditions on both sites are quite similar.

Concerning the conclusion from Andreić (2018) that Zagreb is more severely light-polluted than some other large towns in the world, a few studies that appeared after the first article was prepared sadly confirmed this fact. Without entering any discussion here, the basic information from these studies, including the ones cited by Andreić (2018) is gathered in Table 1.

\section{Conclusions}

A comparison of light pollution data for Merenje, a rural location near Zagreb, to the north, and the RGN location, an urban location near the center of Zagreb, shows that, apart from much brighter night sky bright- ness at the Zagreb site, night sky brightness at both sites follows very similar patterns for clear sky conditions and are often similar for cloudy conditions as well. For both sites, no significant increase in the zenithal night sky brightness was found in the observed period of 2014 - 2017, being about $16.9 \mathrm{mag} / \mathrm{arcsec}^{2}$ for the RGN site and about $18.9 \mathrm{mag} / \mathrm{arcsec}^{2}$ for the Merenje site. Furthermore, the clear/cloudy sky averages for Merenje were found to be about $2.1 \mathrm{mag} / \mathrm{arcsec}^{2}$. Thus, at least for the areas north of Zagreb that are in the shadow of Medvednica Mountain, the contribution of light pollution from Zagreb remains unaltered. No measurements exist for areas to the south, so no conclusions can be made for the situation there.

It was also found that in cloudy conditions, the stronger light pollution of Zagreb is unproportionally more enhanced by the clouds/fog than the lower levels of the light pollution at the Merenje site, stressing the need to control the light pollution of large urban areas more strictly.

Comparison with studies published in the last few years (after the first article was prepared) show that the conclusion from Andreić (2018) is supported by them as well. The new data is summarized in Table $\mathbf{1}$ at the beginning of this paper.

\section{Acknowledgment}

This work was supported by the University of Zagreb support "Mathematical research in Geology" (head T. Malvić) for 2016, "Mathematical research in Geology II" (head T. Malvić) for 2017, "Mathematical research in Geology III" (head T. Malvić) for 2018 and "Mathematical research in Geology IV" (head T. Malvić) for 2019.

\section{References}

Andreić, Ž., Andreić, D., Pavlić, K. (2012): Near infrared light pollution measurements in Croatian sites. Geofizika, 29, 143-156.

Andreić, Ž. (2018): Night sky brightness above Zagreb, Croatia, 2012-2017. The Mining-Geology-Petroleum Engineering Bulletin, 30, 85-94, DOI: 10.17794/rgn.2018.3.9

Cinzano P. (2005): Night sky photometry with Sky Quality Meter. ISTIL Internal report no. 9, Thiene, URL: http://

www.inquinamentoluminoso.it/download/sqmreport.pdf (accessed 19th February 2020.)

Krop-Benesch, A (2019): Licht Aus?: Rowohlt Taschenbuch Verlag, Hamburg, 254p, ISBN 978-3-499-63448-2

Hänel, A., Posch, T., Ribas, S.J., Aubé, M., Duriscoe, D., Jechow, A., Kollath, Z., Lolkema, D.E., Moore, C., Schmidt, N., Spoelstra, H., Wuchterl, G., Kyba, C.C.M. (2017): Measuring night sky brightness: methods and challenges, arXiv:1709.09558v1 [astro-ph.IM], DOI: 10.1016/j.jqsrt.2017.09.008

Marco, E., Rubio, A.M., Montãnez, M.G., Segura, R., Bonet, C., Ruíz, I. (2015): Light pollution in the surroundings of 
Valencia. Anthropic and natural factors, Highlights of Spanish Astrophysics VIII, 908-912.

Pun, C. S. J., So, C. W., Leung, W. Y. and Wong, C. F. (2014): Contributions of artificial lighting sources on light pollution in Hong Kong measured through a night sky brightness monitoring network. arXiv:1401.1200v1 [astro-ph.IM]

Puschnig, J., Posch, T. and Uttenthaler, S. (2014): Night sky photometry and spectroscopy performed at the Vienna University Observatory. Journal of Quantitative Spectroscopy and Radiative Transfer, 139, 64-75. Schnitt, S., Ruhtz, T., Fischer, J., Hoelker, F., Kyba, C. C. M. (2013): Temperature Stability of the Sky Quality Meter. Sensors, 13, 9, 12166-12174, DOI: 10.3390/s130912166

Ribas, J.S., Torra, J., Figueras, F., Paricio, S., Canal-Domingo, R. (2017): Amplification (or not) of Light Pollution due to the presence of clouds, Highlights on Spanish Astrophysics IX, 754-759.

Schnitt, S., Ruhtz, T., Fischer, J., Hölker, F., Kyba, C.C.M. (2013): Temperature Stability of the Sky Quality Meter, Sensors (Basel), 13, 12166-12174.

Ścięzor, T. and Kubala, M. (2014): Particulate matter as an amplifier for astronomical light pollution, MNRAS, 444, 2487-2493

Sharma, I., Mostečak, A., Andreić, Ž. (2015).: Svjetlosno onečišćenje grada Zagreba u periodu Prosinac 2010. - Srpanj 2011. (in Croatian), Rudarsko-geološko-naftni zbornik, 30, 9-17, DOI: 10.17794/rgn.2015.1.3

Yu, J., An, S.-H., Bae, H.-J., Roh, E., Chiang, H., Kim, J., Kim, S., Park, S. (2015): Light Pollution Surveys around the
Seoul Capital Area: Results from 2009 and 2014. XXIX IAU General assembly, Meeting \#29, id.2255081.

Zaninović, K., Gajić-Čapka, M., Perčec Tadić, M., Vučetić, M., Milković, J., Bajić, A., Cindrić, K., Cvitan, L., Katušin, Z., Kaučić, D., Likso, T., Lončar, E., Lončar, Ž., Mihajlović, D., Pandžić, K., Patarčić, M., Srnec, L., Vučetić, V. (2008): Climate atlas of Croatia 1961-1990., 1971-2000, Meteorological and Hydrological Service of Croatia, Zagreb, 200p.

\section{Internet sources:}

Hollan, J. (2008): What is light pollution, and how do we quantify it?. Darksky2008 conference paper, Vienna, August 2008. Updated April 2009., URL: http://amper.ped.muni.cz/ light/lp_what_is.pdf (accessed February $\left.11^{\text {th }}, 2020\right)$.

IDA (2020): URL: https://www.darksky.org/ (accessed February $\left.11^{\text {th }}, 2020\right)$.

SQM-LE (2020): URL: http://unihedron.com/projects/sqm-le/ (accessed February $11^{\text {th }}, 2020$ ).

SQM-LU-DL (2020): http://unihedron.com/projects/sqm-lu$\mathrm{dl} /$ (accessed February $\left.15^{\text {th }}, 2020\right)$.

Unihedron (2020): URL: http://unihedron.com/index.php (accessed February $\left.12^{\text {th }}, 2020\right)$.

Unihedron2 (2020): URL: http://www.unihedron.com/projects/darksky/cd/SQM-LE/SQM-LE_Users_manual.pdf (accessed February $13^{\text {th }}, 2020$ ).

WIKI (2020): URL: https://en.wikipedia.org/wiki/Light_pollution (accessed February 12 $2^{\text {th }}, 2020$ ).

ZZPUZG (2019): URL: https://www.zzpugz.hr/prostorno-uredenje/pp-medvednica/ (accessed June, 10 $0^{\text {th }} 2019$ ). 


\section{SAŽETAK}

\section{Usporedba svjetline noćnoga neba iznad Zagreba i iznad bliske ruralne lokacije za razdoblje od 2014. do 2017 .}

Rezultati praćenja svjetlosnoga onečišćenja u blizini središta Zagreba za razdoblje od 2012. do 2017. prikazani su u nedavnome članku (Andreić, 2018). Ostalo je neodgovoreno kako se ponaša svjetlina noćnoga neba u predgrađima Zagreba i u obližnjemu ruralnom području. Ovaj članak pokušava dati odgovor na to pitanje analizom podataka prikupljenih na jednome ruralnom lokalitetu sjeverno od Zagreba. Glavni je zaključak ovoga rada da svjetlina noćnoga neba na obama mjestima ima vrlo slične obrasce u uvjetima vedra neba, a često je slična i pri oblačnome vremenu. Za oba mjesta nije zabilježeno znatno povećanje zenitne svjetline noćnoga neba u razmatranome razdoblju od 2014. do 2017. Jedina razlika postoji u jačini svjetline noćnoga neba, za koju je srednja vrijednost za RGN lokaciju 16,9 mag/arcsec ${ }^{2}$, odnosno 18,9 mag/arcsec ${ }^{2}$ za lokaciju Merenje. Tako za područja sjeverno od Zagreba koja su u sjeni planine Medvednice nema znatnoga doprinosa svjetlosnoga onečišćenja iz Zagreba. Ne postoje mjerenja za područja južno od Zagreba, tako da se ne može donijeti zaključak o tamošnjoj situaciji. Na kraju je ustanovljeno da je u oblačnim uvjetima jače svjetlosno onečišćenje Zagreba proporcionalno pojačano oblacima/maglom od manjih razina svjetlosnoga onečišćenja na mjestu Merenje.

\section{Ključne riječi:}

svjetlosno onečišćenje, svjetlina noćnoga neba, ALAN evolucija, atmosferski učinci

\section{Authors contribution}

Krešimir Pavlić (PhD, Assistant Professor, Geophysics, Hydrology) provided the statistical data analysis, discussed the meteorological and geographical influences on the results and put the paper together. Željko Andreić (PhD, Full Professor, Physics, Astronomy) gathered data, finished the statistics, produced the graphs and tables used in the paper and discussed the correlations of the Merenje and RGN data. 